\title{
Effects of 2,4-Dichlorophenol on the Expression of Vitellogenin and Estrogen Receptor Genes and Physiology Impairments in Chinese Rare Minnow (Gobiocypris rarus)
}

\author{
Xiaoyan Zhang, Jinmiao Zha, Wei Li, Lihua Yang, Zijian Wang \\ State Key Laboratory of Environmental Aquatic Chemistry, Research Center for \\ Eco-Environmental Sciences, Chinese Academy of Sciences, P.O. Box 2871, \\ Beijing 100085, China
}

Received 18 October 2007; revised 3 January 2008; accepted 30 January 2008

\begin{abstract}
Dichlorophenol (2,4-DCP) is known as a toxicant, but unknown as an environmental endocrine disruptor. In the present work, Chinese rare minnow (Gobiocypris rarus) was exposed to $0.03,0.3$, and $3 \mathrm{mg} / \mathrm{L} \mathrm{2,4-DCP}$ for $3 \mathrm{~d}$ and $0.1,0.3$, and $1 \mathrm{mg} / \mathrm{L} \mathrm{2,4-DCP}$ for $21 \mathrm{~d}$, respectively. Endpoints including somatic index, vitellogenin (VTG) mRNA and protein level, estrogen receptor (ER) mRNA and histopathology were measured. In the $3-d$ exposure experiment, the effect concentrations were $0.3 \mathrm{mg} / \mathrm{L}$ and above, and in 21-d exposure, the effect concentrations were $0.1 \mathrm{mg} / \mathrm{L}$ and above. When exposed to the effect concentrations, GSI was significantly reduced for both male and female, ER mRNA was upregulated in male and downregulated in female. There were no significant variations of VTG mRNA in both male and female in 3-d exposure and in male in 21-d exposure. However, VTG mRNA in female in 21-d exposure was upregulated, corresponding to an increase of VTG protein in serum. Histopathological observation showed that ovaries were degenerated in the effect concentrations, where follicular atresias were more frequently observed. Because the sex hormones related genes and toxicological endpoints were affected in the dose-dependent manner, the results suggest that 2,4-DCP could be a potential endocrine disruptor and might cause adverse effects in female sex organs through interruption of ER-mediated processes. (c) 2008 Wiley Periodicals, Inc. Environ Toxicol 23: 694-701, 2008.
\end{abstract}

Keywords: 2,4-dichlorophenol; histopathology; estrogen receptor; vitellogenin; endocrine disruption; rare minnow (Gobiocypris rarus)

\section{INTRODUCTION}

Chlorophenols are widely used as biocides, flame retardants, wood treatment agents, and ubiquitously distributed in aquatic environment. Evidences showed that this group of chemicals can cause detrimental biological effects includ-

Correspondence to: Z. Wang; e-mail: wangzj@rcees.ac.cn

Contract grant sponsor: National Natural Science Foundation of China. Contract grant numbers: 20737003, 20621703.

Contract grant sponsor: National Basic Research Program of China.

Contract grant number: 2003CB415005.

Published online 17 March 2008 in Wiley InterScience (www. interscience.wiley.com). DOI 10.1002/tox.20375 ing chronic toxicity, mutagenicity and carcinogenicity (House et al., 1997; Amer and Aly, 2001; USEPA, 2002). Among them, 2,4-dichlorophenol (2,4-DCP) is the most abundant chlorophenol in aquatic environment (House et al., 1997). 2,4-DCP was usually used as a mothproofing agent, germicide, antiseptic and precursor in the production of herbicide 2,4-dichlorophenoxyacetate (Doedens, 1963; Freiter, 1979). In addition, 2,4-DCP also was a metabolite of the pesticide 2,4-dichlorophenoxyacetic acid and released into the environment as an intermediate compound from paper mills and chemical industries. The concentration of 2,4-DCP in rivers were less than $1 \mu \mathrm{g} / \mathrm{L}$ in English (House et al., 1997) and ranged from 20 to $40 \mathrm{ng} / \mathrm{L}$ in China 
(Gao et al., in press). Concentration levels of 2,4-DCP in drinking-water were usually lower than the detection limit (Dietz and Traud, 1978). Because of the great solubility, high mobility, and wide distribution in aquatic environment, 2,4-DCP has been taken as one of the priority pollutants in effluent (USEPA, 1979). The detected frequency of 2,4-DCP in urine samples were 64\% whereas 1000 persons were exposed to pesticides (Bukowska, 2003). In addition, permanent impairment of vision or blindness of the eyes and severe injury of the upper respiratory tract were observed while human and animals were exposed to 2,4DCP (USEPA, 2000). Significant percentage of chromosome aberrations and sperm head abnormalities were induced while mice were injected to $180 \mathrm{mg} / \mathrm{kg}$ 2,4-DCP (Amer and Aly, 2001). The activity of erythrocyte superoxide dismutase in human erythrocytes decreased with the increasing dose of 2,4-DCP, whereas glutathione peroxidase activity increased at about $250 \mathrm{ppm}$ (Bukowska, 2003). In the former studies, the LC50 value of 2,4-DCP for fish ranged from 7.0 to $11.6 \mathrm{mg} / \mathrm{L}$ were reported (Phipps et al., 1981; Broderius et al., 1995; Kishino and Kobayashi, 1996), and the no-observed-effects concentration (NOEC) of acute toxicity in medaka was $3.3 \mathrm{mg} / \mathrm{L}$ (Kondo et al., 2005). Some studies reported that 2,4-DCP affects in vitro administration causes changes in glutathione and antioxidant enzyme activities (Bukowska et al., 2003, 2007). However, no experimental evidences have been reported about the endocrine disruption effects of 2,4-DCP.

Rare minnow (Gobiocypris rarus) is one of the model animals for toxicological studies and belongs to the largest family of Cyprinidae. They mostly distribute in upstream of the Yangtze River, Sichuan Province, China. The fish is small and easy to culture in the laboratory. Relatively short life cycle, spawning hundreds of eggs with high fertilization rate and hatching rate make them the perfect model fish for the laboratory (Zha et al., 2007).

The study was aimed to determine endocrine disruption related effects including the growth, gonadosomatic index (GSI), hepatosomatic index (HSI), organ impairs, the expression levels of estrogen receptor (ER) and vitellogenin (VTG) genes in liver after exposure.

\section{MATERIALS AND METHODS}

\section{Experimental Fish}

The brood stock of rare minnow was raised in flow-through system with dechlorinated tap water (Zha et al., 2007). Sexually mature fish ( $\sim 9$ months old) were the offspring from the same pair of brood stock. During breeding, fish were subjected to a light/dark cycle of $16 / 8 \mathrm{~h}$ at $25 \pm 1{ }^{\circ} \mathrm{C}$. The brood stock was fed newly hatched brine shrimp (Artemia nauplii) in the morning and granule food (TetraMin, Germany) in the afternoon.

\section{Chemicals}

2,4-DCP was purchased from Sigma (Deisenhofen, Germany). Stock solution of 2,4-DCP was prepared by diluting the chemical in high-performance liquid chromatography (HPLC)-grade DMSO and mixing with distilled water. The final solvent concentration in the water was less than $0.01 \%$.

\section{Exposure and Experimental Design}

Male or female fish were identified by examining the distance between the abdomen fin and stern fin and also the shape of the abdomen. The stock solutions were prepared weekly in HPLC-grade DMSO and dosed to glass mixing vessels by means of a peristaltic pump at a rate of $1 \mathrm{~mL} /$ min. Then, the solutions were diluted with dechlorinated tap water to the mixing vessels at a rate of $4 \mathrm{~L} / \mathrm{h}$. The flow rate of dilution water was checked daily by using a measuring cylinder. After $96 \mathrm{~h}$ of exposure, the no-observed effect concentration of 2,4-DCP on rare minnow was calculated to $2.8 \mathrm{mg} / \mathrm{L}$ under flow-through conditions, which was similar to the report on medaka (Kondo et al., 2005). In the first present experiment, after 1 week of acclimatization, adult fish were exposed to nominal concentrations of $0.03,0.3$ and $3 \mathrm{mg} / \mathrm{L} \mathrm{2,4-DCP}$ for $3 \mathrm{~d}$. In the sequential experiment, adult fish were exposed to nominal concentration of $0.1,0.3,1 \mathrm{mg} / \mathrm{L} 2,4-\mathrm{DCP}$ and E2 (100 ng/L) was as positive control for $21 \mathrm{~d}$. Treated and control fish (males:females $=1: 1$ ) were randomly exposed in $18-\mathrm{L}$ aquaria (20 fish/tank). Two duplicates were conducted for each concentration gradient and control. Fish were under flowthrough conditions at $25 \pm 1{ }^{\circ} \mathrm{C}$ with a photoperiod of $16: 8 \mathrm{~h}$ (light:dark). Fish were generally fed with a commercial granule food (TetraMin, Germany) at a rate of $0.1 \%$ body weight per day and a dry diet of brine shrimp was supplemented.

\section{Specimen Preparation}

Fish were dissected and the livers and gonads were isolated and flash-frozen in liquid nitrogen and stored at $-70^{\circ} \mathrm{C}$ until analysis. The body, liver and gonads of the rest fish were weighted. The GSI was calculated as follows: GSI = (weight of the gonads in $\mathrm{mg}$ ) $\times 100 /$ (weight of the total body in milligram). The HSI was calculated as follows: HSI $=$ (weight of the liver in $\mathrm{mg}) \times 100 /($ weight of the total body in milligram). Gonads and livers were fixed in Bouin's solution (71\% saturated picric acid, $24 \%$ formaldehyde, 5\% glacial acetic acid; Sigma-Aldrich, USA). After $24 \mathrm{~h}$, samples were transferred to $70 \%$ ethanol. The sections were cut at 3-4 $\mu \mathrm{m}$ and stained with hematoxylin and eosin (H\&E) and the section of the paraffin blocks were monitored microscopically. Blood was collected in a heparinized microcapillary tube, measured the volume, and transferred to the sampling buffer, $20 \mathrm{mM}$ Tris ( $\mathrm{pH} 7.5$ ) containing 
$1 \mathrm{mM}$ EDTA, $150 \mathrm{mM} \mathrm{NaCl}$, and $25 \mathrm{KIU} / \mathrm{mL}$ approtinin. The samples were immediately centrifuged $(8000 \mathrm{~g}, 10 \mathrm{~min}$, $4^{\circ} \mathrm{C}$ ), and the plasma were kept frozen at $-80^{\circ} \mathrm{C}$ until use. Plasma VTG levels were measured using a competitive enzyme-linked immunosorbent assay (ELISA). The procedure was according to the method described previously (Brion et al., 2002). The working range of the assay was from 30 to $1500 \mathrm{ng} / \mathrm{mL}$ (20-80\% binding), and the detection limit was $15 \mathrm{ng} / \mathrm{mL}$ for purified VTG. To avoid the matrix effect, a dilution of at least 1:100 was chosen for the routine assay. Purified VTG was used as a standard, and VTG in diluted samples was measured in triplicate.

\section{RNA Isolation}

Total RNA was isolated from livers of individual male and female fish and then was purified from lysates using a spin column method (RNeasy; Qiagen, Valencia, CA) according to the manufacturer's instructions. RNA samples were treated with DNase I (Ambion, UK) to remove contaminating genomic DNA and repurified by spin column (RNeasy, Qiagen). Then RNA samples were stored in $-80^{\circ} \mathrm{C}$ until the process of reverse-transcriptase.

\section{RT-PCR and Quantitative of PCR Products Using Real-time PCR}

RT-PCR and real-time PCR were performed by methods described previously (Zhang et al., 2008). The RT-PCR was carried out with total RNA isolated from male and female fish. Oligonucleotide primers to VTG were designed on conserved amino acid sequences region obtained by comparing VTG sequences from Carp (Сyprinus carpio) (BAD51933), zebrafish (Danio rerio) (XP_685166), rainbow trout (Oncorhynchus mykiss) (JC4956), Melanogrammus aeglefinus (AAK15158), Verasper moseri (BAD93695), Cyprinodon variegates (AAG30349), Sillago japonica (BAC20186) and Pagrus major (BAE43870). Using the primers, we amplified the VTG fragment from the female liver. The GenBank accession No. is EF095728. Species-specific primer sequences for VTG were based on EF095728: 5'AAATTCATGGTGCTGCTGAAG- $3^{\prime} ; \quad 5^{\prime}$-CCTTTCATC CAGTCTGCAAC- $3^{\prime}$. The PCR reaction was: $94^{\circ} \mathrm{C}$ for 5 min for denaturation, followed by 32 cycles of $94^{\circ} \mathrm{C}$ for $30 \mathrm{~s}, 58^{\circ} \mathrm{C}$ for $30 \mathrm{~s}$, and $72^{\circ} \mathrm{C}$ for $1 \mathrm{~min}$. The nucleotidespecific primers were designed across the DNA-binding domain and ligand-binding domain because of the high sequence similarity of the ER $\beta$ among the vertebrate species. The sequence alignment of available sequences was obtained from several species including zebrafish (NM_174862), Salmo salar (AAR92486), Ovis aries (AAD55772), rainbow trout (CAC06714), Atlantic croaker (Micropogonias undulatus) (Q92731), Kryptolebias marmoratus (DQ927045), Spinibarbus denticulatus
(ABF56052). Using the primers, ER $\beta$ was isolated from adult liver (GenBank accession no. is EF190319). Forward and reverse primers for ER cDNA were as follows: 5'-AACAGACCGCCACATTAG-3'; 5'-GAGCCACCT GAGATTTACC- $3^{\prime}$. The PCR conditions were: denaturation at $94^{\circ} \mathrm{C}$ for $10 \mathrm{~min} ; 35$ cycles of denaturation at $94^{\circ} \mathrm{C}$ for $30 \mathrm{~s}$; annealing at $55^{\circ} \mathrm{C}$ for $45 \mathrm{~s}$; and extension at $72^{\circ} \mathrm{C}$ for $30 \mathrm{~s}$.

Amplification and quantitation of cDNA were performed in the Bio-Rad iCycler iQ5 Multicolor Real-Time PCR Detection System (Bio-Rad, USA). Each reaction contained $11.25 \mu \mathrm{L}$ of Quant $2 \mathrm{X}$ iQ SYBR Green PCR master mix (Bio-Rad, USA), $100 \mathrm{nM}$ each of forward and reverse primers and $1 \mu \mathrm{L}$ cDNA template. Thermal cycling was initiated with a first denaturation step of $10 \mathrm{~min}$ at $95^{\circ} \mathrm{C}$, followed by 35 cycles of $95^{\circ} \mathrm{C}$ for $10 \mathrm{~s}$ and $60^{\circ} \mathrm{C}$ for $30 \mathrm{~s}$ and the amplification fluorescence was read at $55^{\circ} \mathrm{C}$ and $60^{\circ} \mathrm{C}$ at the end of the cycle. Following the final cycle, the reactions were denatured over a $35^{\circ} \mathrm{C}$ temperature gradient from 60 to $95^{\circ} \mathrm{C}$ to determine the quality of PCR products. Real-time PCR amplification data were analyzed using the Bio-Rad iCycler iQ5 Multicolor Real-Time PCR Optical System Software Version 3.1. Standard curves for the quantitation of VTG, ER, and $\beta$-actin were constructed using serial dilutions of plasmids containing VTG, ER, and $\beta$-actin sequences. All experiments were done twice and samples were run in triplicate each time.

\section{Statistics}

All statistical analyses were performed with the SPSS (version 11.0; USA). Prior to data analysis, the $\chi^{2}$ analyses, Student $t$-tests (parametric data) or Mann-Whitney rank sum tests (nonparametric, nonequal variances) were used to test for differences between water control and solvent control groups. The experimental data were checked for assumptions of normality and homogeneity of variance using Kolmogorov-Smirnov one-sample test and Levene's test, respectively. Statistical significance was set at $p \leq 0.05$.

\section{RESULTS}

\section{Mortality and Growth}

No mortality was observed in both 3-d and 21-d exposure experiments. There were no significant differences for body length of female and male between treatments and controls at the end of exposure (Table I). The body weight of male treated at 0.3 or $3 \mathrm{mg} / \mathrm{L}$ was significantly lower than those in controls in 3-d exposure experiment $(p<0.05)$. In contrast, no significant change of body weight was observed in female. Under 21-d treatment, the weights of male and female were both lower than those in controls at concentrations above $0.3 \mathrm{mg} / \mathrm{L}$. 
TABLE I. Total length, body weight, and tissue index of rare minnow under 3-d exposure

\begin{tabular}{|c|c|c|c|c|c|c|c|c|}
\hline \multirow{2}{*}{$\begin{array}{l}\text { 2,4-Dichlorophenol } \\
\text { Concentration }(\mathrm{mg} / \mathrm{L})\end{array}$} & \multicolumn{2}{|c|}{ Total Length (mm) } & \multicolumn{2}{|c|}{ Body Weight (mg) } & \multicolumn{2}{|c|}{ Gonadosomatic Index } & \multicolumn{2}{|c|}{ Hepatosomatic Index } \\
\hline & Female & Male & Female & Male & Female & Male & Female & Male \\
\hline WDC & $42.8 \pm 2.3$ & $42.2 \pm 1.7$ & $838 \pm 24$ & $810 \pm 20$ & $15.1 \pm 6.5$ & $3.9 \pm 1.1$ & $2.0 \pm 0.6$ & $1.3 \pm 0.6$ \\
\hline DMSO & $42.4 \pm 3.4$ & $41.9 \pm 2.3$ & $840 \pm 23$ & $809 \pm 16$ & $15.4 \pm 4.6$ & $4.1 \pm 1.2$ & $1.7 \pm 0.6$ & $1.0 \pm 0.2$ \\
\hline 0.03 & $42.7 \pm 1.5$ & $42.1 \pm 1.9$ & $852 \pm 20$ & $780 \pm 12$ & $14.5 \pm 4.4$ & $3.4 \pm 1.1$ & $2.0 \pm 0.5$ & $1.3 \pm 0.3$ \\
\hline 0.3 & $43.2 \pm 2.5$ & $41.8 \pm 1.8$ & $843 \pm 24$ & $677 \pm 27^{\mathrm{a}}$ & $10.3 \pm 6.8^{\mathrm{a}}$ & $2.9 \pm 1.2^{\mathrm{a}}$ & $1.6 \pm 0.7$ & $1.4 \pm 0.6$ \\
\hline 3 & $42.3 \pm 1.6$ & $42.6 \pm 2.0$ & $874 \pm 21$ & $696 \pm 19^{\mathrm{a}}$ & $11.0 \pm 4.6^{\mathrm{a}}$ & $2.4 \pm 0.1^{\mathrm{a}}$ & $1.7 \pm 0.8$ & $1.2 \pm 0.2$ \\
\hline
\end{tabular}

${ }^{a}$ Significantly different from the pooled controls $(p<0.05)$.

\section{Tissue Somatic Indices}

In the 3-d exposure experiment, the GSI of female or male at $0.03 \mathrm{mg} / \mathrm{L} 2,4-\mathrm{DCP}$ did not show significant change, whereas that of female and male exposed to 0.3 or $3 \mathrm{mg} / \mathrm{L}$ 2,4-DCP was significantly lower than those of the water control and solvent control ( $p<0.05$; Table I). Under 21-d exposure, GSI of male or female was significantly affected when exposed to concentrations above $0.1 \mathrm{mg} / \mathrm{L}$ treatment (Fig. 1) $(p<0.05)$. However, the HSI of female and males at all treatments did not show statistically differences compared to the controls.

\section{Histopathology}

No phenomena of testis-ova were observed in treatments and controls at the end of exposure. Histological inspection of ovaries in controls revealed all stages of oocyte development including primary, secondary and tertiary follicles [Fig. 2(A)] for 3-d exposure. Serious degeneration and impairments of ovaries were induced at $0.3 \mathrm{mg} / \mathrm{L}$ treatment, and follicular atresia was more frequently observed in the ovary [Fig. 2(B)]. The same phenomenons were observed in ovaries at concentrations above $0.1 \mathrm{mg} / \mathrm{L} \mathrm{2,4-DCP}$ for $21 \mathrm{~d}$ (data not show). Increasing of ovarian interstitial stroma and many previtellogenic oocytes in ovaries were detected in $3 \mathrm{mg} / \mathrm{L} \mathrm{2,4-DCP}$. The testis of adult rare minnow displayed normal spermatogenesis (spermatozoa, spermatocytes, and spermatids) [Fig. 2(C)]. For males, no significant histological changes were found in the testis in treatments. Male and female liver alterations were characterized by a hypertrophy of hepatocytes and an enlargement of the cell nuclei, accompanied by a distinct reduction of glycogen deposits [Fig. 2(F,H)].

\section{Quantitation of ER and VTG by Real-time PCR}

To compare the accuracy of efficiency-corrected relative quantification, amplification efficiency was derived from standard curves. All standard curves for VTG, ER and $\beta$ actin mRNA were linear over five or six orders of magnitude with the linear correlation coefficients higher than 0.99. The amplification efficiency for VTG, ER, and $\beta$-actin were between 98 and $104 \%$ and the difference between target and internal control genes was $<5 \%$. The $\beta$-actin gene was used as internal control gene and no significant changes of mRNA levels were observed between water control and solvent control. In 3-d exposure experiment, results showed that ER mRNA was significantly downregulated in female at 0.03 and $0.3 \mathrm{mg} / \mathrm{L}(p<0.05)$. In male fish, ER mRNA was significantly upregulated at higher concentrations above $0.3 \mathrm{mg} / \mathrm{L}$ (Fig. 3) ( $p<0.05)$. VTG mRNA of all treatments was not significantly induced (Fig. 3) $(p<$ 0.05). In 21-d exposure experiment, ER mRNA was significantly downregulated in female at all concentrations and ER mRNA was significantly upregulated in males at
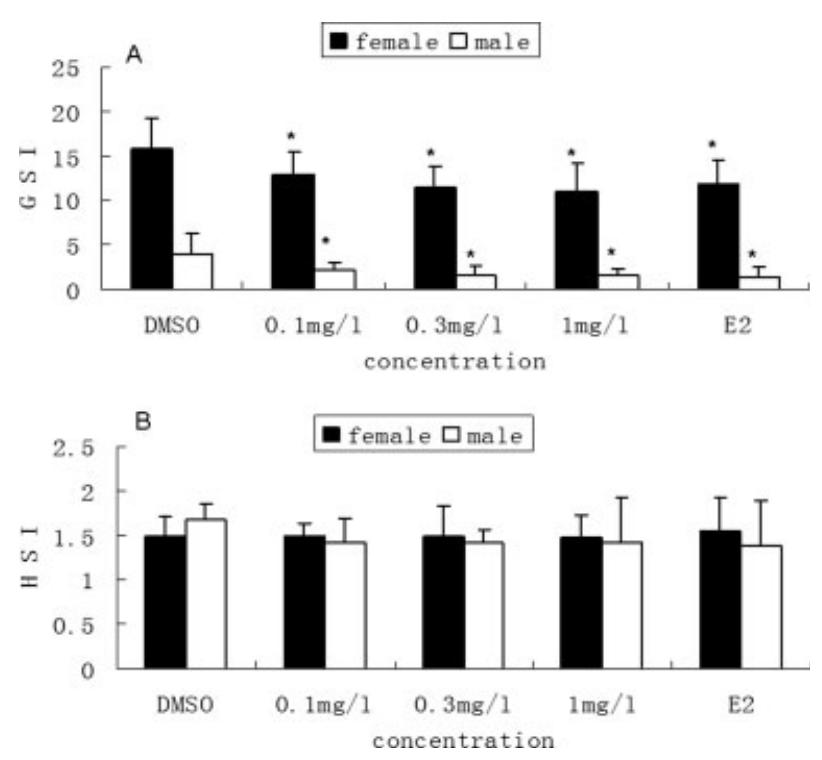

Fig. 1. (A) Gonadosomatic index (GSI) for adult fish compared with that of the control under 2,4-dichlorophenol $(2,4-$ DCP) exposure for $21 \mathrm{~d}$. Significant changes were observed at all concentration; (B) Hepatosomatic index (HSI) for adult fish in comparison with that of the control. There were no statistical significant differences compared with the control. Data were expressed as mean \pm standard deviation. The numbers in each treatment were 12 . The asterisks $\left(^{*}\right)$ indicate statistical significant differences with the control $(p<$ 0.05). 

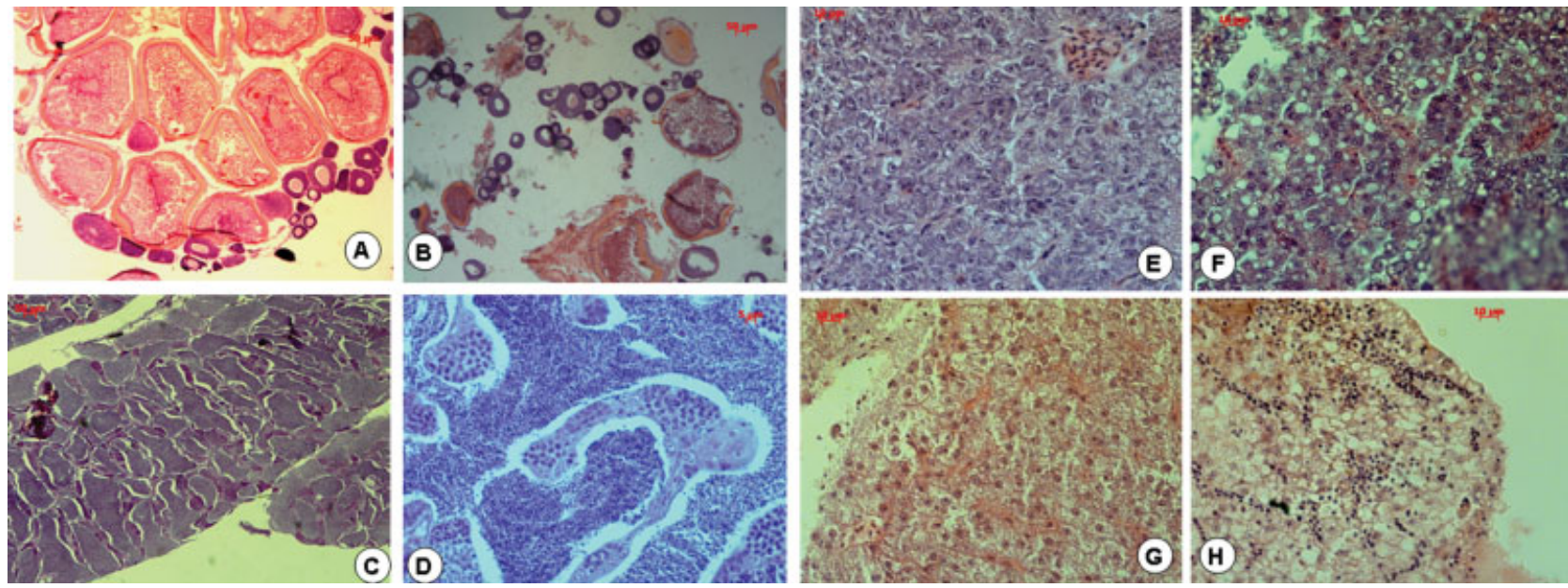

Fig. 2. Light micrographs of gonad and hepatic tissues in male and female adult rare minnow, stained with hematoxylin and eosin: (A) normal mature ovary from control; (B) degeneration ovary from $3 \mathrm{mg} / \mathrm{L}$ 2,4-dichlorophenol (2,4-DCP) (C) normal mature testis from control; (D) testis section treated with $3 \mathrm{mg} / \mathrm{L} 2,4-\mathrm{DCP}(100 \times)$. (E) Normal hepatic tissue from the male control; $(F)$ hepatic tissue from $3 \mathrm{mg} / \mathrm{L} \mathrm{2,4-DCP}$ treated group in males, $(G)$ normal hepatic tissue from the female control; $(H)$ hepatic tissue from $3 \mathrm{mg} / \mathrm{L}$ $2,4-D C P$-treated group in females $(400 \times)$. [Color figure can be viewed in the online issue, which is available at www.interscience.wiley.com.]

concentrations above $0.1 \mathrm{mg} / \mathrm{L}$ treatments (Fig. 4) $(p<$ $0.05)$. VTG mRNA was significantly upregulated in female fish at all concentrations $(p<0.05)$, similar as that
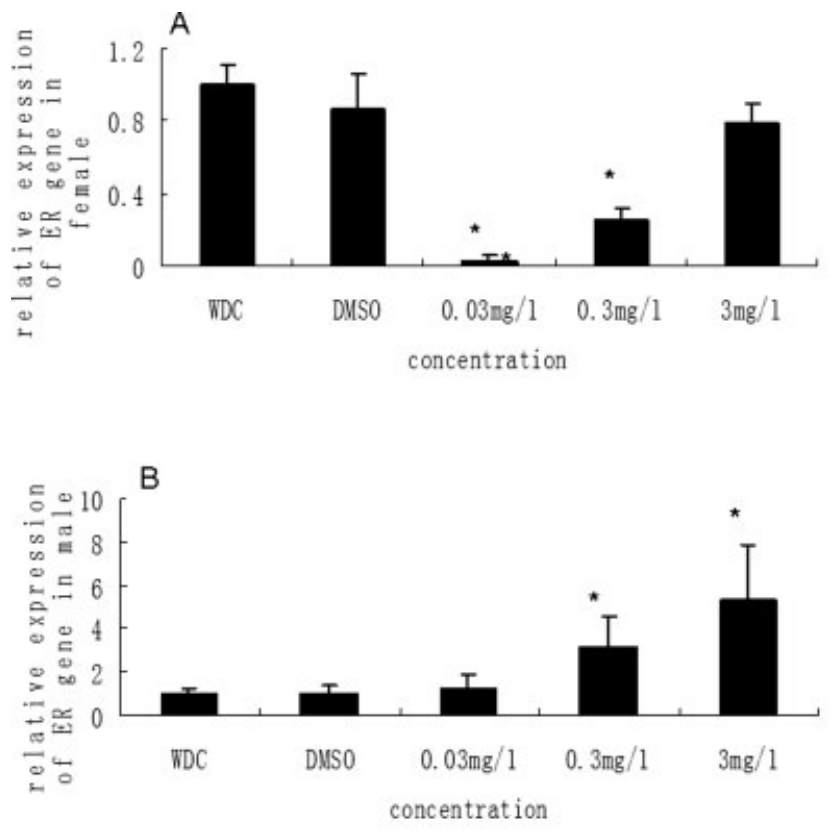

observed in positive control (Fig. 4). No effects in VTG mRNA were observed in male fish in all concentrations for 3-d and 21-d exposure experiments.
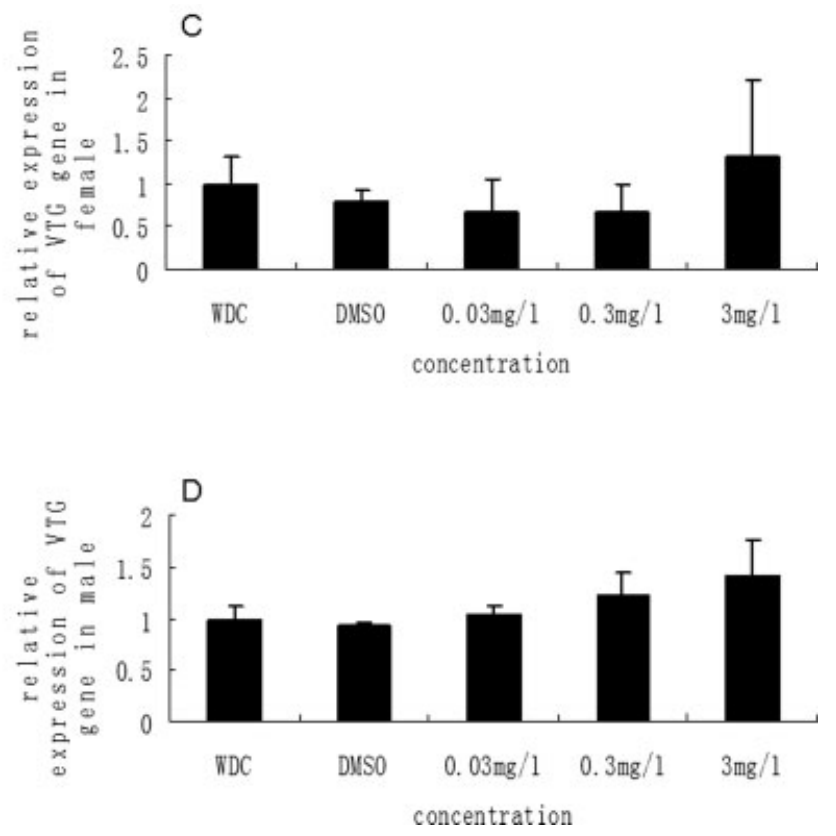

Fig. 3. Graphical analysis of ER gene mRNA levels in male $(A)$ and female $(B)$ rare minnow liver treated with 2,4- dichlorophenol (2,4-DCP), the water control (DWC) and solvent control for $3 \mathrm{~d}$. Graphical analysis of VTG gene mRNA levels in male (C) and female (D) rare minnow liver treated with 2,4-DCP, DWC and solvent control for $3 \mathrm{~d}$. Data were expressed as mean \pm standard deviation. The numbers in each treatment were six. The asterisks $\left(^{*}\right)$ denote statistically significant difference compared with the solvent control (t-test) $(p<0.05)$, respectively. 

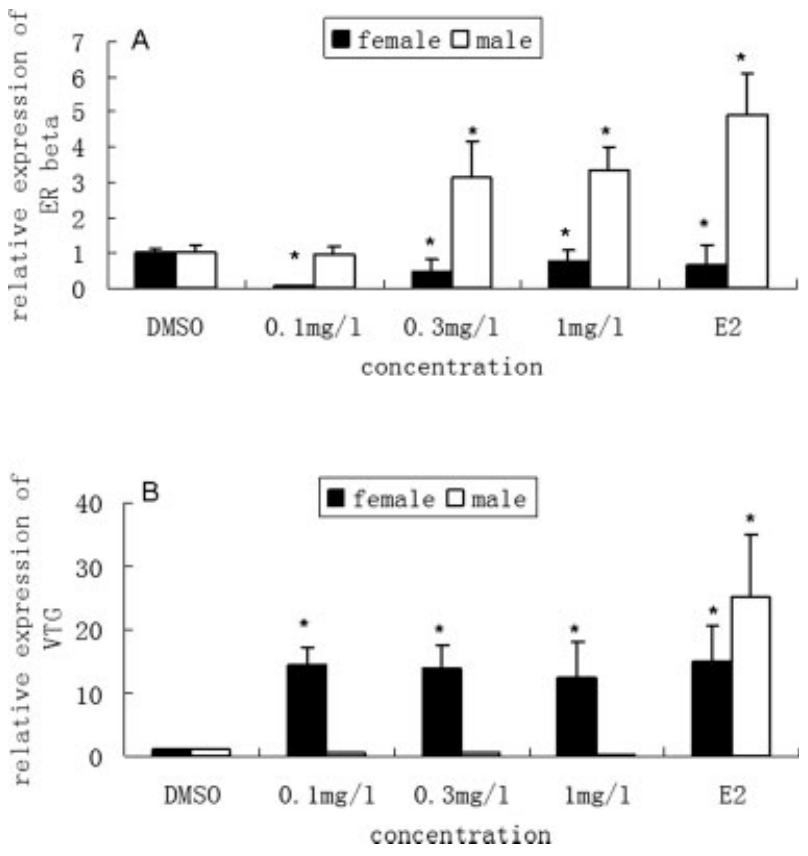

Fig. 4. (A) Graphical analysis of ER gene mRNA levels in male and female rare minnow liver treated with 2,4-dichlorophenol (2,4-DCP), the positive control and solvent control for $21 \mathrm{~d}$. (B) Graphical analysis of VTG gene mRNA levels in male and female rare minnow liver treated with 2,4-DCP, DWC, and solvent control for $21 \mathrm{~d}$. Data were expressed as mean \pm standard deviation. The numbers in each treatment were six. The asterisks $\left(^{*}\right)$ denote statistically significant difference compared with the solvent control ( $t$-test) $(p<0.05)$, respectively.

\section{Plasma VTG Protein Levels}

In 21-d exposure experiment, plasma VTG protein was induced significantly in concentrations of 0.3 and $1 \mathrm{mg} / \mathrm{L}$ $(p<0.05)$. In contrast, no plasma VTG concentrations were detected in male fish compared with the positive control (Fig. 5).

\section{DISCUSSION}

Endocrine disrupting chemicals (EDCs) could alter endocrine functions through a variety of mechanisms, including nuclear receptor-mediated changes in protein synthesis, interference with membrane receptor binding, steroidogenesis or synthesis of other hormones (Inoshita et al., 2003). Mice lacking of estrogen receptor exhibit normal reproductive tract development, but are infertile (Couse et al., 1999). Potent EDCs such as bisphenol A, octylphenol and diethylstilbestrol disrupted the secretion of VTG and sex hormones by effecting the expression level of ER mRNA (Khurana et al., 2000).
Rare minnow exposed to $0.3 \mathrm{mg} / \mathrm{L} 2,4-\mathrm{DCP}$ or above in the 3-d and 21-d exposures showed both toxic symptom and endocrine disrupting effects. The results showed that VTG mRNA and plasma VTG level were significantly upregulated in female fish for 21-d treatments compared with the controls; however, the expression of hepatic estrogen receptor gene, ER $\beta$, was significantly downregulated in female. Previous work showed that ER $\beta$ could act as the transcription repression factor (An et al., 1999), which could inhibit VTG mRNA expression and downstream VTG protein synthesis. On the other side, induction of VTG gene and plasma VTG level in male fish were not observed, whatever the expression of hepatic ER $\beta$ was significantly upregulated in male. Some studies have reported that the upregulation of hepatic ER mRNA was observed in male fish exposed to E2, but no significant difference in the expression level of hepatic VTG mRNA (Sabo-Attwood et al., 2004; Yamaguchi et al., 2005). Therefore, 2,4-DCP could activate the expression of ER $\beta$ mRNA without affecting VTG protein pathway in male fish. Alternations in sex hormone related gene expressions and in indicators of sex organs demonstrated that 2,4-DCP could be an endocrine disruptor.

It was reported that ER $\alpha$ is auto-regulated by the presence of EREs and expressed in many tissues of fish species (Petit et al., 1999; Rogers et al., 2000; Mortensen and Arukwe, 2007). However, the function and regulation of ER $\beta$ in fish species is still under debate. In the present study, effect of 2,4-DCP on ER $\beta$ gene expression was different between male and female. An et al. (1999) have reported that $\mathrm{ER} \beta$ was more potent than $\mathrm{ER} \alpha$ at repressing gene expression. In addition, several studies have reported that ER $\alpha$ and $\beta$ had different or even opposite biological actions (Karas et al., 1999; Mortensen and Arukwe, 2007). Downregulation of the ER $\beta$ and upregulation of ER $\alpha$ mRNA were observed when Atlantic salmon (S. salar) was exposed to tributyltin (Mortensen and Arukwe, 2007). Alignment of ER $\beta$ with ER $\alpha$ indicates that the receptors shares $96-97 \%$ and $53-60 \%$ amino acid similarity in the

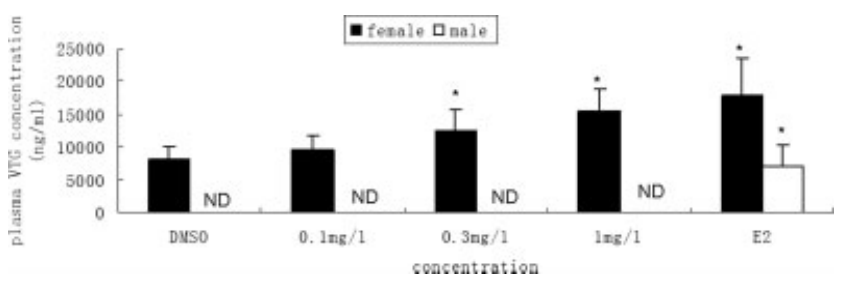

Fig. 5. Plasma vitellogenin concentrations of male and female rare minnow under 2,4-dichlorophenol exposure for 21 d. 17 $\beta$-estrogen was as positive control. Data were expressed as mean \pm standard deviation. The numbers in each treatment were 10 . The asterisks $\left(^{*}\right)$ denote statistically significant difference compared with the solvent control $(t-$ test) $(p<0.05)$, respectively. ND: not detected. 
DBD and the LBD, respectively. The AF- 2 core sequences in $\mathrm{ER} \alpha$ and $\beta$ isoforms are virtually identical; however, the significant differences can be detected between two aminoterminal domains, from which it can be expected that the two receptors might interact differently with co-activator proteins or group of co-factors.

Some endpoints such as body length, body weight, and tissue somatic indices, indicate general measure of the growth status. And histology is a qualitative and semi-quantitative tool widely used to describe alternations, detect and localize specific changes. In a 3-d exposure experiment, the body weight of female did not decreased in 0.3 and $3 \mathrm{mg} / \mathrm{L}$ treatments, but the body weight of male fish was significantly affected. The different effects of male and female might be attributed to the difference of feeding activity.

The GSI in males and females was significantly decreased in both short period and long period exposure $(p<0.05)$. Similar phenomenons were observed when rare minnow were exposed to 5 and $25 \mathrm{ng} / \mathrm{L} 17 \mathrm{a}$-ethynylestradiol (EE2) (Zha et al., 2007). The low GSI in female might be due to ovary degeneration (Scholz and Gutzeit, 2000). Furthermore, gonadal histopathology revealed that adverse effects occurred in the 0.3 and $3 \mathrm{mg} / \mathrm{L} 2,4-\mathrm{DCP}$ treatments. Seki et al. (2002) reported regression of ovaries in adult medaka exposed to $488 \mathrm{ng} / \mathrm{L}$ EE2 for 3 weeks. Preponderance of primary follicles and in the presence of several atretic follicles was observed whereas fathead minnows were exposed to higher concentrations of E2 (MilesRichardson et al., 1999). The changes in estrogen receptor activity may be involved in the diseases including disorders in the reproduction, cancers in the gonads and impairments in sex organs (Calle et al., 2002; Sharpe, 2003).

In the present study, the results included histopathology, the changes in GSI, VTG mRNA and protein, and the ER $\beta$ expression should be related to the disruption of the endocrine system. The results also show that 2,4-DCP could be one of potential EDCs. Furthermore, to obtain reliable information on wildlife and human health, future work should be focused on the detection of other genes and biomarkers associated with development and maintenance of the endocrine system.

\section{REFERENCES}

Amer SM, Aly FAE. 2001. Genotoxic effect of 2,4-dichlorophenoxy acetic acid and its metabolite 2,4-dichlorophenol in mouse. Mutat Res-Gen Tox En 494:1-12.

An J, Ribeiro RC, Webb P, Gustafsson JA, Kushner PJ, Baxter JD, Leitman DC. 1999. Estradiol repression of tumor necrosis factor-alpha transcription requires estrogen receptor activation function- 2 and is enhanced by coactivators. Proc Natl Acad Sci USA 96:15161-15166.

Brion F, Nilsen BM, Eidem JK, Goksoyr A, Porcher JM. 2002. Development and validation of an enzyme-linked immunosor- bent assay to measure vitellogenin in the zebrafish (Danio rerio). Environ Toxicol Chem 21:1699-1708

Broderius SJ, Kahl MD, Hoglund MD. 1995. Use of joint toxic response to define the primary mode of toxic action for diverse industrial organic chemicals. Environ Toxicol Chem 14:15911605

Bukowska B. 2003. Effects of 2,4-D and its metabolite 2,4-dichlorophenol on antioxidant enzymes and level of glutathione in human erythrocytes. Comp Biochem Physiol C Toxicol Pharmacol 135:435-441.

Bukowska B, Michalowicz J, Krokosz A, Sicinska P. 2007. Comparison of the effect of phenol and its derivatives on protein and free radical formation in human erythrocytes (in vitro). Blood Cells Mol Dis 39:238-244.

Calle EE, Frumkin H, Henley SJ, Savitz DA, Thun MJ. 2002. Organochlorines and breast cancer risk. CA Cancer J Clin 52:301-309.

Couse JF, Hewitt SC, Bunch DO, Sar M, Walker VR, Davis BJ, Korach KS. 1999. Postnatal sex reversal of the ovaries in mice lacking estrogen receptor $\alpha$ and $\beta$. Science 286:23282331.

Dietz F, Traud J. 1978. Trace analysis of phenols, especially chlorophenols in water, by GC. Vom Wasser 51:235-237.

Doedens JD. 1963. Chlorophenols. In: Kirk RE, Othmer DF, editors. Encyclopedia of Chemical Technology, 2nd ed. New York: Wiley. pp 325-338.

Freiter ER. 1979. Chlorophenols. In: Kirk RE, Othmer DF, editors. Encyclopedia of Chemical Technology, 3rd ed, Vol. 5. New York: Wiley. pp 864-872.

Gao JJ, Liu LH, Liu XR, Zhou HD, Huang SB, Wang ZJ. Levels and spatial distribution of chlorophenols-2,4-dichlorophenol, 2,4,6-trichlorophenol, pentachlorophenol in surface water of China. Chemosphere, in press.

House WA, Leach D, Long JLA, Cranwell P, Smith C, Bharwaj L, Meharg A, Ryland G, Orr DO, Wright J. 1997. Micro-organic compounds in the Humber rivers. Sci Total Environ 194195:357-371.

Inoshita H, Masuyama H, Hiramatsu Y. 2003. The different effects of endocrine-disrupting chemicals on estrogen receptormediated transcription through interaction with coactivator TRAP220 in uterine tissue. J Mol Endocrinol 31:551-561.

Karas RH, Hodgin JB, Kwoun M, Aronovitz M, Mackey W, Gustafsson JA, Korach KS, Smithies O, Mendelsohn ME. 1999. Estrogen inhibits the vascular injury response in estrogen receptor $\beta$-deficient female mice. Proc Natl Acad Sci USA 96: 15133-15136.

Khurana S, Ranmal S, Ben-Jonathan N. 2000. Exposure of newborn male and female rats to environmental estrogens: delayed and sustained hyperprolactinemia and alterations in estrogen receptor expression. Endocrinology 141:4512-4517.

Kondo T, Yamamoto H, Tatarazako N, Kawabe K, Koshio M, Hirai N, Morita M. 2005. Bioconcentration factor of relatively low concentrations of chlorophenols in Japanese medaka. Chemosphere 61:1299-1304.

Kishino T, Kobayashi K. 1996. Acute toxicity and structure-activity relationships of chlorophenols in fish. Water Res 30:387392. 
Miles-Richardson SR, Kramer VJ, Fitzgerald SD, Render JA, Yamini B, Barbee SJ, Giesy JP. 1999. Effect of waterborne exposure of $17 \beta$-estradiol on secondary sex characteristics and gonads of fathead minnow (Pimephales promelas). Aquat Toxicol 47:129-145.

Mortensen AS, Arukwe A. 2007. Modulation of xenobiotic biotransformation system and hormonal responses in Atlantic salmon ( $S$. salar) after exposure to tributyltin (TBT). Comp Biochem Physiol C Toxicol Pharmacol 145:431-441.

Rogers SA, Llewellyn L, Wigham T, Sweeney GE. 2000. Cloning of the Atlantic salmon (Salmo salar) estrogen receptor-alpha gene. Comp Biochem Physiol B Biochem Mol Biol 125:379385 .

Petit FG, Metivier R, Valotaire Y, Pakdel F. 1999. Synergism between a half-site and an imperfect estrogen-responsive element, and cooperation with COUP-TFI are required for estrogen receptor (ER) to achieve a maximal estrogen-stimulation of rainbow trout ER gene. Eur J Biochem 259:385-395.

Phipps GL, Holcombe GW, Fiandt JT. 1981. Acute toxicity of phenol and substituted phenols to the fathead minnow. Bull Environ Contam Toxicol 26:585-593.

Sabo-Attwood T, Kroll KJ, Denslow ND. 2004. Differential expression of largemouth bass (Micropterus salmoides) estrogen receptor isotypes alpha, beta, and gamma by estradiol. Mol Cell Endocrinol 218:107-118.

Scholz S, Gutzeit HO. 2000. 17-alpha-ethinylestradiol affects reproduction, sexual differentiation and aromatase gene expres- sion of the medaka (Oryzias latipes). Aquatic Toxicol 50:363373.

Seki M, Yokota H, Matsubara H, Tsuruda Y, Maeda M, Tadokoro H, Kobayashi K. 2002. Effect of ethinylestradiol on the reproduction and induction of vitellogenin and testis-ova in medaka (Oryzias latipes). Environ Toxicol Chem 21:1692-1698.

Sharpe RM. 2003. The oestrogen hypothesis-Where do we stand now? Int J Androl 26:2-15.

United States Environmental Protection Agency. 1979. Toxic pollutant effluent standards. 40 CFR 401.15.

USEPA Office of Pollution Prevention and Toxics and Occupational Safety and Health Administration. 2000. Chemical advisory and notice of potential risk: Skin exposure to molten 2,4-dichlorophenol (2,4-DCP) can cause rapid death. pp 113.

Yamaguchi A, Ishibashi H, Kohra S, Arizono K, Tominaga N. 2005. Short-term effects of endocrine-disrupting chemicals on the expression of estrogen-responsive genes in male medaka (Oryzias latipes). Aquat Toxicol 72:239-249.

Zha JM, Wang ZJ, Wang N, Ingersoll C. 2007. Histological alternation and vitellogenin induction in adult rare minnow (Gobiocypris rarus) after exposure to ethynylestradiol and nonylphenol. Chemosphere 66:488-495.

Zhang XY, Zha JM, Wang ZJ. 2008. Influences of 4-nonylphenol on doublesex and mab-3-related transcription factor 1 gene expression and vitellogenin mRNA induction of adult rare minnow (Gobiocypris rarus). Environ Toxicol Chem 27:196-205. 